\title{
PENENTUAN NILAI CBR DAN NILAI PENYUSUTAN TANAH TIMBUNAN (SHRINKAGE LIMIT) DAERAH BARITO KUALA
}

\author{
Ahmad Norhadi (1), Muhammad Fauzi ${ }^{(1)}$, M. Yogi Indra Rukmana (2)
}

(1) Staf Pengajar D3 Jurusan Teknik Sipil Politeknik Negeri Banjarmasin

(2) Mahasiswa D3 Jurusan Teknik Sipil Politeknik Negeri Banjarmasin

\begin{abstract}
Ringkasan
Tanah dalam ilmu teknik sipil, mempunyai peranan penting karena tanah sebagai pendukung kekuatan kontruksi di atasnya, maka dari itu pentingnya mengetahui sifat-sifat tanah, nilai activity, dan persentase penyusutan pada tanah timbunan yang akan digunakan guna menghindari tidak tercapainya atau kegagalan dalam perencanan saat menggunakan tanah asli, maka dilakukanlah penelitian tanah asli dari Jl. Semangat Karya yang bertepatan di daerah Barito Kuala.

Pengujian yang dilakukan dengan alasan untuk mengetahui sifat sifat tanah asli yang akan digunakan dalam kegiatan kontruksi terdiri dari kadar air sesuai dengan SNI 031965:2008, berat jenis sesuai dengan SNI 03-1964:2008, batas plastis sesuai dengan SNI 03-1966:2008, batas cair sesuai dengan SNI 03-1967:2008, hydrometer sesuai dengan SNI 03-3423:2008, nilai activity, CBR sesuai SNI 03 - 1744 - 1989, dan penelitian shringkage limit sesuai SNI 03 - 1996 - 1990.

Berdasarkan penelitian dan perhitungan data dari sampel tanah (disturbed) daerah Barito Kuala, maka didapatkan nilai sifat sifat tanah seperti kadar air (W) 98,52\%, berat jenis (Gs) 2,415, batas cair (LL) 45\%, batas plastis (PL) 33,85\%, Plastisitas Indeks (PI) 11,2\% Kadar Air Optimum (Omc) 34,9\%, Kepadatan kering 1,120 Kg/Cm3 dan CBR design sebesar 3,9\%, hasil perhitungan nilai Shrinkage Limit sebesar 38\% dan nilai Activity tanah sebesar 2,6. Maka dapat diambil kesimpulan bahwa tanah ini termasuk OL dengan O untuk lanau organic dikarenakan hasil analisis hydrometer didapatkan ukuran butiran 0,002 mm sampai 0,0074 dengan tingkat plastisitas, kadar air yang cukup tinggi, sehingga termasuk tanah yang tidak baik jika digunakan untuk menahan suatu beban kontruksi di atasnya.
\end{abstract}

Kata kunci : Cbr ,Shrinkage limit, dan Activity.

\section{PENDAHULUAN}

\section{Latar Belakang}

Dalam kegiatan kontruksi jalan banyak didapati lokasi yang tanah aslinya berupa Lempung. Lempung terdiri dari butiran yang sangat kecil dan menunjukkan sifat-sifat plastisitas, dan tanah lempung ini termasuk ke dalam tanah berbutir halus. Tanah lempung dalam mendukung beban pondasi sangat bergantung pada sejarah geologi, kadar air dan kandungan mineralnya. Tanah lempung dinyatakan sebagai lunak, sedang, atau kaku, tergantung dari kadar air seperti yang dinyatakan dalam konsistensi. Tanah dalam ilmu teknik sipil, mempunyai peranan penting karena tanah sebagai pendukung kekuatan kontruksi di atasnya.

Pembangunan kian berkembang pesat mengharuskan diadakannya penelitian khususnya pada tanah asli yang ada.
Pentingny amengetahui sifat-sifat tanah, nilai activity, dan persentase penyusutan pada tanah timbunan yang akan digunakan guna menghindari tidak tercapainya atau kegagalan dalam perencanan saat menggunakan tanah asli. Karena itu dalam penelitian ini diambil tanah asli dari daerah Barito Kuala yang bertepatan di Jl. Semangat Karya, Alalak. Metode penelitan nilai CBR sesuai SNI 03 - 1744 - 1989, dan penelitian shringkage limit sesuai SNI 03 $1996-1990$

Pengujian nilai activity, CBR dan persentasi penyusutan dilakukan dengan alasan untuk mengetahui sifat sifat tanah asli yang akan digunakan dalam kegiatan kontruksi, maka penelitian dengan judul "Penentuan Nilai CBR dan Persentasi Penyusutan Timbunan (Shrinkage Limit) Pada Tanah Lunak Daerah Barito Kuala" diharapkan dapat menjadi solusi dalam 
mengetahui persentase penyusutan tanah asli dalam suatu kontruksi jalan.

\section{Rumusan Masalah}

1. Bagaimana sifat tanah dan nilai CBR tanah?

2. Berapakah nilai persentase penyusutan tanah?

3. Berapakah nilai activity tanah ?

\section{Tujuan Penelitian}

1. Mengetahui sifat tanah dan nilai CBR tanah.

2. Mengetahui nilai persentase penyusutan tanah

3. Mengetahui nilai activity tanah

\section{Batasan Masalah}

1. Sampel tanah yang digunakan pada pengujian berasal dari daerah Tanah asli di daerah JI. Semangat Karya, Alalak, Kabupaten Barito Kuala dengan keadaan disturbed (terganggu) karena diambil tidak menggunakan tabung.

2. Pengujian dilakukan di Laboratorium Geoteknik dan Transportasi Politeknik Negeri Banjarmasin dengan macam pengujian yaitu Batas Cair dan Batas Plastis, Kadar air, Berat Jenis, Hidrometer, Nilai Activity, CBR, dan Persentase Penyusutan Tanah (Shrinkage Limit).

\section{KAJIAN PUSTAKA}

Tanah lempung merupakan agregat partikel-partikel berukuran mikroskopik dan submikroskopik yang berasal dari pembusukan unsur-unsur kimiawi penyusun batuan. Tanah lempung bersifat sangat keras dalam keadaan kering dan plastis dalam selang kadar air sedang. Pada keadaan air lebih tinggi, lempung bersifat lengket (kohesif) dan sangat lunak; (Das, 1985 dalam Aniessa Rinny, 2010)

Lanau (silt) adalah partikel batuan yang berukuran dari $0,002 \mathrm{~mm}$ sampai 0,0074 juga bahan yang merupakan peralihan antara lempung dan pasir-halus. Kurang plastis dan lebih mudah ditembus air dari pada lempung dan memperlihatkan sifat dilatasi yang tidak terdapat pada lempung. Dilatasi ini menunjukkan gejala perubahan isi apabila lanau itu dirubah bentuk- nya. Juga, lanau akan menunjukkan gejala untuk menjadi "quick" ("hidup") apabila diguncang atau digetarkan.

Dalam klasifikasi tanah sistem unified, Cassagrande membagi tanah atas 3 (tiga) kelompok (Sukirman, 1992) yaitu :
- Tanah berbutir kasar, < 50\% lolos saringan No. 200.

- Tanah berbutir halus, > 50\% lolos saringan No. 200.

- Tanah organik yang dapat dikenal dari warna, bau dan sisa-sisa tumbuhtumbuhan yang terkandung di dalamnya.

Sedangkan, klasifikasi berdasarkan unified system (Das, 1995), tanah dikelompokkan menjadi :

- Tanah berbutir kasar adalah tanah yang lebih dan $50 \%$ bahanya tertahan pada ayakan No. 200. Tanah butir kasar terbagi atas kerikil dengan simbol $\mathrm{G}$ (gravel), dan pasir dengan simbol $\mathrm{S}$ (sand).

- Tanah butir halus adalah tanah yang lebih dan $50 \%$ bahannya lewat pada saringan No. 200. Tanah butir halus terbagi ataslanau dengan simbol $\mathrm{M}$ (silt), lempung dengan simbol C (clay), serta lanau dan lempung organik dengan symbol $\mathrm{O}$, bergantung pada tanah itu terletak pada grafik plastisitas. Tanda $L$ untuk plastisitas rendah dan tanda $\mathrm{H}$ untuk plastisitas tinggi.

Adapun simbol-simbol lain yang digunakan dalam klasifikasi tanah ini adalah :

- W yaitu well graded (tanah dengan gradasi baik)

- P yaitu poorly graded (tanah dengan gradasi buruk)

- L yaitu low plasticity (plastisitas rendah) (LL<50)

- $\mathrm{H}$ yaitu high plasticity (plastisitas tinggi) (LL>50)

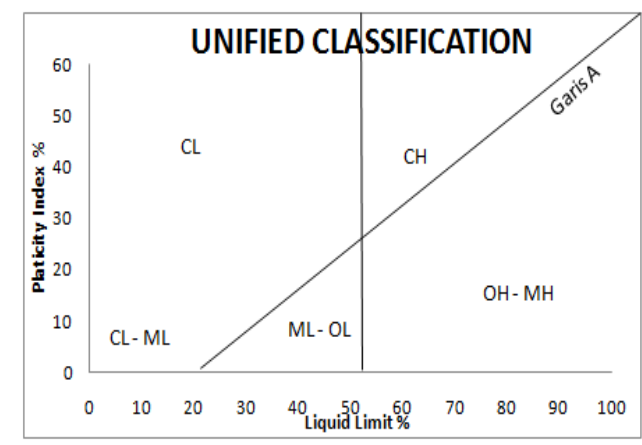

\section{Gambar 1. Unified Classification}

Untuk penentuan kadar air untuk tanah menurut SNI (1965:2008) penentuan kadar air untuk tanah dan batuan dilakukan di laboratorium terhadap contoh tanah atau batuan yang diambil dari lapangan. Kegunaan hasil uji kadar air ini dapat diterapkan untuk menentukan konsistensi perilaku material dan sifatnya, pada tanah 
kohesif konsistensi tanah tergantung dari nilai kadar airnya. Disamping itu pula nilai kadar air ini dapat digunakan untuk pengujian lainnya seperti pada pengujian penentuan batas cair dan batas plastis tanah. Dan rumus perhitungannya sebagai berikut :

$$
W=\frac{W 1-W 2}{W 2-W 3} X 100 \%
$$

Dimana $\mathrm{W}$ kadar air (\%), $\mathrm{W}_{1}$ berat cawan dan tanah basah (gram), $W_{2}$ berat cawan dan tanah kering (gram), $W_{3}$ berat cawan (gram), $\left(\mathrm{W}_{1}-\mathrm{W}_{2}\right)$ berat air (gram) dan $\left(\mathrm{W}_{2}\right.$ $W_{3}$ ) berat tanah kering (gram).

Pelaksanaan pengujian berat jenis tanah mengacu kepada SNI (1964:2008). Kegunaan hasil uji berat jenis tanah ini dapat diterapkan untuk menentukan konsistensi perilaku material dan sifatnya. Dan rumus perhitungannya sebagai berikut :

$$
\frac{\text { BeratJenis, } T x}{\left(20^{\circ} \mathrm{C}\right)}=\frac{W t}{(W 1+(W 4-W 3))}
$$

Dimana $W_{1}$ berat contoh tanah kering oven (gram), $W_{4}$ berat piknometer berisi air pada temperature $T_{x}$ (gram), $W_{3}$ berat piknometer berisi air dan tanah pada temperature $T_{x}$ (gram), $T_{x}$ Temperatur air dalam piknometer ketika berat $\mathrm{W}_{3}$ ditentukan $\left({ }^{\circ} \mathrm{C}\right)$

Menurut SNI (1967:2008) penentuan batas cair tanah ini dilakukan dilaboratorium terhadap contoh tanah yang diambil dari lapangan. Kegunaan hasil uji batas cair ini dapat diterapkan untuk menentukan konsistensi perilaku material dan sifatnya pada tanah kohesif, konsistensi tanah tergantung dari nilai batas cairnya. Disamping itu nilai batas cair ini dapat digunakan untuk menentukan nilai indeks plastisitas tanah yaitu nilai batas cair dikurangi dengan nilai batas plastis.

Menurut SNI (1966:2008) standar cara uji penentuan batas plastis tanah bertujuan untuk menentukan batas terendah kadar air ketika tanah dalam keadaan plastis, dan angka indeks plastisitas suatu tanah.

Batas plastis dihitung berdasarkan persentasi berat air terhadap berat tanah kering pada benda uji. Pada cara uji ini, material tanah yang lolos saringan ukuran $0,425 \mathrm{~mm}$ atau saringan No.40, diambil untuk dijadikan benda uji kemudian dicampur dengan air suling atau air mineral hingga menjadi cukup plastis untuk digeleng/ dibentuk bulat panjang hingga mencapai diameter $3 \mathrm{~mm}$. Metode penggelengan dapat dilakukan dengan telapak tangan atau dengan alat penggeleng batas plastis (prosedur alternative). Benda uji yang mengalami retakan setelah mencapai diameter $3 \mathrm{~mm}$ diambil untuk diukur kadar airnya. Kadar air yang dihasilkan dari pengujian tersebut merupakan batas plastis tanah tersebut.

Menurut SNI (3423:2008) cara uji ini dilakukan untuk mendapatkan gradasi tanah pada klasifikasi tanah perencanaan maupun pengawas dilapangan. Cara uji ini ada dua cara yaitu cara uji analisis hydrometer dan cara uji analisis saringan.

Peralatan yang digunakan adalah oven pengering, timbangan, alat pengaduk mekanis, hydrometer, silinder sedimentasi, thermometer, saringan, bak air, gelas kimia, alat pengukur waktu, wadah/cawan, dan batang kaca. Bahan disperse yang digunakan adalah sodium heksametaphospat, dan larutan garam.

Cara uji analisis hydrometer sebagai berikut : Tanah yang butirnya sangat kecil yakni lebih kecil dari No.200 (0,075mm) tidak efektif lagi disaring dengan saringan yang lebih kecil dari No.200 bila ingin menentukan besaran butirnya. Oleh sebab itu tanah dicampur dengan air suling yang ditambah bahan disperse, sehingga tanah dapat terurai, kemudian dipantau dengan alat hydrometer. Kecepatan mengendap butiran dihubungkan dengan rumus stoke guna mendapatkan distribusi butiran tanah.

Menurut pedoman kontruksi bangunan (Pd T-10-2005-B) batas Atterberg dan fraksi lempung dapat dikombinasikan menjadi satu parameter yang dinamakan tingkat keaktifan (activity). Pada umumnya, tanah dengan indeks plastisitas (PI) kurang dari $15 \%$ tidak memperlihatkan perilaku pengembangan. Untuk tanah dengan PI lebih besar dari $15 \%$, kadar lempung dan batas Atterbergnya harus diuji. Persamaan berikut untuk menentukan tingkat keaktifan suatu tanah :

$\mathrm{AC}=\frac{P I}{C F}$

Dimana Ac adalah tingkat keaktifan (tanpa satuan), PI adalah indeks plastisitas (\%), CF adalah persentase fraksi lempung (\%)

Tabel 1. Korelasi tingkat keaktifan denganpotensi pengembangan

\begin{tabular}{|c|c|}
\hline Tingkat Keaktifan & Potensi Pengembangan \\
\hline$<0,75$ & Tidak Aktif \\
$0,75-1,25$ & Normal \\
$>1,25$ & Aktif \\
\hline
\end{tabular}

(Sumber :Pd T-10-2005-B) 
Untuk tanah yang dipadatkan dengan pemadatan standar pada kadar air optimum, tingkat keaktifannya ditentukan berdasarkan persamaan berikut :

$$
\mathrm{A}_{\mathrm{C}}=\frac{P I}{C F-10}
$$

Dimana Ac adalah tingkat keaktifan (tanpa satuan), PI adalah indeks plastisitas (\%), CF persentase fraksi lempung berdiameter kurang dari $0,002 \mathrm{~mm}$ (\%), 10 adalah konstanta.

Hasil perhitungan tingkat keaktifan dengan persamaan di atas dikaitkan dengan persentase fraksi lempungnya, kemudian diplot ke dalam grafik pada Gambar 6 untuk memperoleh besarnya tingkat potensi mengembang tanah yang dipadatkan.

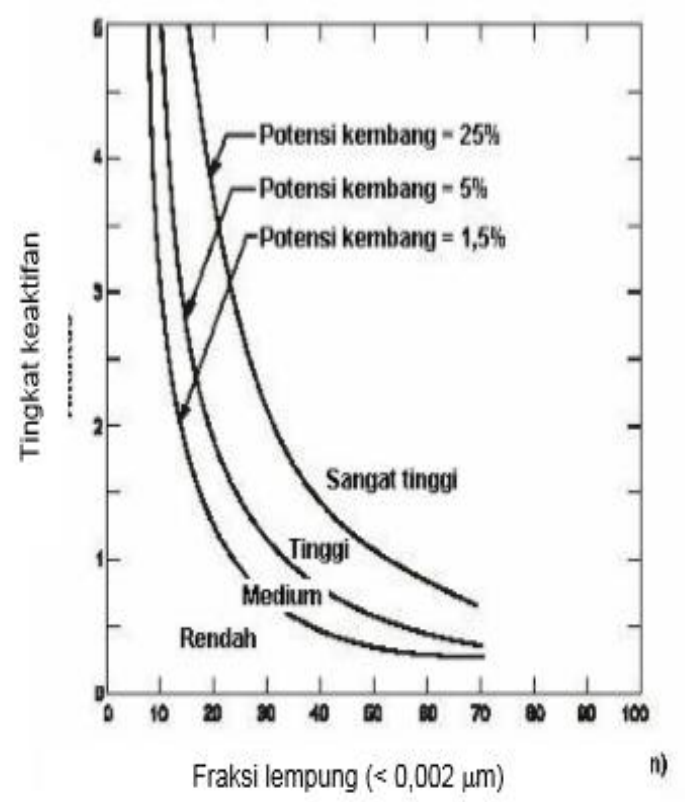

Gambar 2. Klasifikasi potensi kembang

Suatu tanah akan menyusut apabila air yang dikandungnya secara perlahan-lahan hilang dalam tanah. Dengan hilangnya air secara terus menerus, tanah akan mencapai suatu tingkat keseimbangan dimana penambahan kehilangan air tidak akan menyebabkan perubahan volume. Kadar air dinyatakan dalam persen, dimana perubahan volume suatu massa tanah terhenti didefinisikan sebagai batas susut (Shrinkage Limit).

Uji batas susut (ASTM Test Designation D-427) dilakukan di laboratorium dengan menggunakan suatu mangkok porselin yang mempunyai diameter kira-kira 1.75 in $(44,4$ $\mathrm{mm})$ dan tinggi kira-kira 0.5 in (12.7 mm). Bagian dalam dari mangkok dilapisi dengan vaselin (petroleum jelly), kemudian diisi dengan tanah basah sampai penuh. Permukaan tanah di dalam mangkok kemudian diratakan dengan menggunakan penggaris yang bersisi lurus sehingga permukaan tanah tersebut menjadi sama tinggi dengan sisi mangkok. Berat tanah basah di dalam mangkok ditentukan. Tanah di dalam mangkok kemudian dikeringkan di dalam oven. Volume dari contoh tanah yang telah dikeringkan ditentukan dengan cara menggunakan air raksa.

Uji pemadatan tanah (compaction) yang dilakukan dilaboratorium umumnya adalah uji pemadatan proctor (proctor compation test). Uji pemadatan tersebut ada dua macam, yaitu uji proctor standar (standard proctor test) dan uji proctor dimodifikasi (modified proctor test).

Percobaan dalam uji pemadatan proctor pada umumnya dilakukan beberapa kali, sehingga pada akhirnya didapat kepadatan kering (berat volume kering) maksimum dan kadar air optimum.

CBR pertama kali diperkenalkan oleh California Difision of Highway pada tahun 1928. Orang yang banyak memperpopulerkan metode ini adalah O.J. Porter. CBR adalah perbandingan Antara beban yang dibutuhkan untuk penetrasi contoh tanah sebesar 0,1 " / 0,2 " dengan beban yang ditahan batu pecah standar pada penetrasi 0,1" / 0,2". Harga CBR yang didapat dinyatakan dalam persen. Dengan demikian harga CBR adalah nilai yang menyatakan kualitas tanah dibandingkan dengan bahan standar berupa batu pecah yang mempunyai nilai CBR sebesar $100 \%$ dalam memikul beban. Beban yang digunakan untuk melakukan penetrasi bahan standar dapat dilihat pada tabel 2

Tabel 2. Beban yang dibutuhkan untuk penetrasi bahan standar

\begin{tabular}{|c|c|c|}
\hline $\begin{array}{c}\text { Penetrasi } \\
\text { (inci) }\end{array}$ & $\begin{array}{c}\text { Beban Standar } \\
\text { (lbs) }\end{array}$ & $\begin{array}{c}\text { Beban } \\
\text { Standar (lbs) }\end{array}$ \\
\hline 0,1 & 3000 & 1000 \\
0,2 & 4500 & 1500 \\
0,3 & 5700 & 1900 \\
0,4 & 6900 & 2300 \\
0,5 & 7800 & 6000 \\
\hline
\end{tabular}




\section{METODE PENELITIAN}

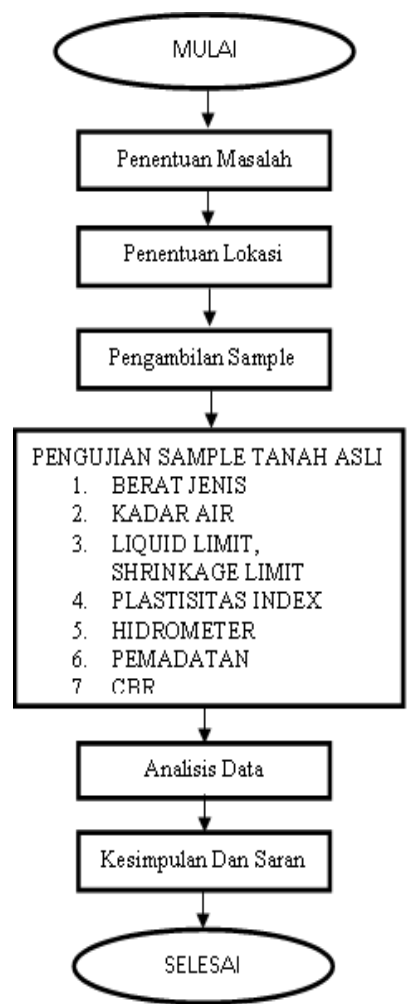

Gambar 3. Diagram Metode Penelitian

\section{HASIL}

\section{Hasil Pengujian Tanah Asli}

\section{Kadar Air}

Pengujian kadar air sesuai dengan SNI 03-1971-1990 dilakukan sebanyak tiga kali dengan masing masing dua sample dan didapatkan hasil air rata rata disetiap pengujian, yaitu $103,5 \%$ pada pengujian pertama , 99,87\% pada pengujian kedua dan $92,17 \%$ pada pengujian ketiga. Dari pengujian ketiga tersebut didapatkan nilai rata-rata sebesar $98,513 \%$.

\section{Berat Jenis}

Pengujian kadar air sesuai dengan 1964:2008, ASTM D854-02dilakukan sebanyak tiga kali dengan masing masing dua sample dan didapatkan hasil rata rata berat jenis disetiap pengujian, yaitu 2,415 pada pengujian pertama, 2,414 pada pengujian kedua dan 2,415 pada pengujian ketiga. Dari pengujian ketiga tersebut didapatkan nilai rata-rata sebesar 2,3148.

\section{Batas Plastis dan Batas Cair}

Pengujian Batas Cair sesuai dengan SNI-03967 - 1990 dilakukan sebanyak tiga kali dengan masing masing 4 sample dengan jumlah ketukan yang berbeda sedangkan Pengujian kadar air sesuai dengan SNI 03 1966 - 1990 dilakukan sebanyak tiga kali dengan masing masing 2 sample. Dari data kadar air optimum dan plastisitas indeks dapat diketahui Plastisitas indeks sebesar 10,1\% dan Liquid limit sebesar 42,6\%.maka tanah dapat diklasifikasikan sebagai Lempung Lanau dengan grafik hubungan Antara Plastisitas indeks dan Liquid Limit

\section{Batas Susut}

Pengujian Batas Susut dilakukan sebanyak tiga kali dengan masing masing dua sample dan didapatkan hasil air rata rata disetiap pengujian, yaitu $35.8 \%$ pada pengujian pertama, $37 \%$ pada pengujian kedua dan $36.6 \%$ pada pengujian ketiga. Dari pengujian ketiga tersebut didapatkan nilai rata-rata sebesar $36.5 \%$.

\section{Hydrometer}

Pengujian hydrometer dilakukan sebanyak tiga kali dan didapatkan nilai persentase lempung (tanah dengan ukuran kurang dari $0.002 \mathrm{~mm}$ ) yaitu $5 \%$ pada pengujian pertama, $4 \%$ pada pengujian kedua dan $4.5 \%$ pada pengujian ketiga. Dari pengujian ketiga tersebut didapatkan nilai rata-rata sebesar $4.5 \%$.

\section{Activity (aktivitas tanah)}

Angka Aktivitas tanah yang di dapat sebesar 2,68 termasuk deskripsi tanah sangat aktif karena lebih dari 2.

\begin{tabular}{|c|c|}
\hline Descripsi & Activity \\
\hline Tidak Aktif & $<0.75$ \\
Normal & $0.75-1.25$ \\
Aktif & $1.25-2$ \\
Sangat Aktif & $>2$ \\
(e.g.bentoni'e) & 6 or more \\
\hline
\end{tabular}

Sumber : Manual of Soil Laboratory Testing Volume. 1 Head KH, ELE International Ltd

\section{Pemadatan}

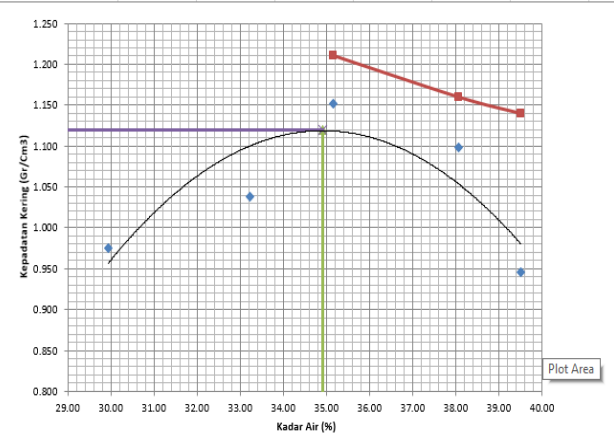

Gambar 4. Hubungan Kadar Air dan Kepadatan Kering 
Dari hasil percobaan kepadatan kering dan kadar air didapatkan hasil grafik hubungan yang hasilnya adalah pada kadar air optimum sebesar $34,9 \%$ dan didapatkan angka kepadatan kering sebesar $1,120 \mathrm{Gr} / \mathrm{Cm}^{3}$

\section{California Bearing Ratio}

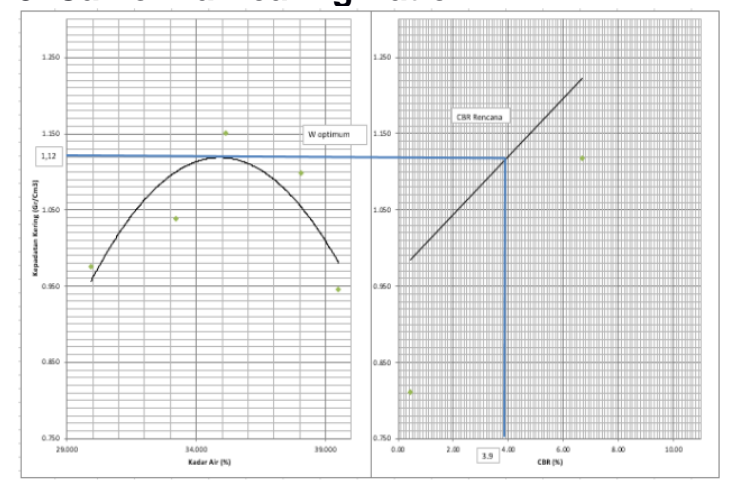

Gambar 5. CBR Design

Setelah data Pengujian Pemadatan dan dari ketiga macam pengujian CBR dengan jumlah tumbukan 10, 30, dan 65 diketahui maka dengan cara menghubungkan grafik pemadatan dan grafik CBR bisa didapatkan CBR design sebesar 3,9\%.

\section{KESIMPULAN DAN SARAN}

\section{Kesimpulan}

a. Dari hasil pengujian didapatkan nilai sifat sifat tanah seperti kadar air (W) 98,52\%, berat jenis (Gs) 2,415, batas cair (LL) $45 \%$, batas plastis (PL) 33,85\%,Plastisitas Indeks (PI) $11,2 \%$ Kadar Air Optimum (Omc) 34,9\% , Kepadatan kering $\left(\gamma d 1,120 \quad \mathrm{Kg} / \mathrm{Cm}^{3}\right.$ dan CBR design sebesar $3,9 \%$. berdasarkan pengeplotan pada grafik klasifikasi tanah unifiedmaka dapat diambil kesimpulan bahwa tanah ini termasuk OL dengan $O$ untuk lanau organic diakarenakan hasil analisis hydrometer didapatkan ukuran butiran $0,002 \mathrm{~mm}$ sampai 0,0074 dengan tingkat plastisitas, dan kadar air yang cukup tinggi.

b. Dari hasil perhitungan nilai Shrinkage Limit yang di hasilkan sebesar $38 \%$ dapat disimpulkan bahwa tanah Lunak Daerah Barito Kuala memiliki tingkat perubahan volume tanah yang cukup besar.

c. Nilai activity tanah yang sebesar 2,6 menunjukan bahwa tanah Lunak Daerah Barito Kuala termasuk tanah yang aktif, yang memiliki kemampuan mengembang cukup besar.

\section{Saran}

Tanah asli dapat digunakan sebagai lantai kerja timbunan, namun dianjurkan untuk dapat melakukan pencampuran untuk memperbaiki sifat sifat tanah dengan pasir/kapur atau sejenisnya

\section{DAFTAR PUSTAKA}

[1] Hardiyatmo, Hary Christady. 1992. Mekanika Tanah 1. PT. Gramedia Pustaka Utama. Jakarta

[2] M. Das, Braja, Noor Endah, Indrasurya B. Mochtar. 1988. Mekanika Tanah (Prinsip-prinsip Rekayasa Geoteknis). Erlangga. Surabaya

[3] Putri Zainanda, Soraya. 2012. Pengaruh Waktu Perendaman Terhadap Daya Dukung Tanah Lempung Plastisitas Rendah yang Distabilisasi Menggunakan Abu Gunung Merapi. Skripsi Universitas Lampung. Lampung.

[4] Verhoef, PNW. 1994. Geologi Untuk Teknik Sipil. Erlangga. Jakarta 